\title{
Impact on Physiological Parameters upon PRSV Infection in Different Genotypes of Carica papaya L. and Vasconcellea species
}

\author{
Linta Vincent $^{1^{*}}$, K. Soorianathasundaram ${ }^{2}$, M.R. Dinesh ${ }^{3}$ and K.S. Shivashankara ${ }^{4}$ \\ ${ }^{1}$ Division of Fruit Crops, ICAR-IIHR, Bangalore, Karnataka, India \\ ${ }^{2}$ Department of Fruit Crops, HC\&RI, TNAU, Coimbatore, Tamil Nadu, India \\ ${ }^{3}$ ICAR-IIHR, Bangalore, Karnataka, India \\ ${ }^{4}$ Division of Plant Physiology and Biochemistry, ICAR-IIHR, Bangalore, Karnataka, India
}

*Corresponding author

\section{Keywords \\ Papaya (Carica papaya L., family Caricaceae), Carica papaya and \\ Vasconcellea cauliflora \\ Article Info \\ Accepted: \\ 18 August 2018 \\ Available Online: \\ 10 September 2018}

\section{A B S T R A C T}

Papaya is major tropical fruit gaining importance throughout the tropics and subtropics but there is a severe restriction in its production due to the serious disease known as Papaya Ring Spot Virus $(P R S V-P)$. No papaya variety till date was identified as having durable resistance to $P R S V$ - $P$; whereas several species of Vasconcellea, a close relative of papaya was reported to have heritable resistance to Papaya Ring Spot Virus. To understand these changes in physiological parameters upon PRSV infection this study was carried out by involving six Carica papaya varieties, two intergeneric hybrids of Carica papaya and Vasconcellea cauliflora and three Vasconcellea species. The physiological parameters viz., photosynthetic rate $\left(\mathrm{P}_{\mathrm{N}}\right)$, stomatal conductance $(\mathrm{gs})$ and transpiration rate $(\mathrm{E})$ were measured before inoculation, and subsequently 7 days post inoculation ( $7 \mathrm{dpi}$ ) with $P R S V$, $14 \mathrm{dpi}$ and $30 \mathrm{dpi}$. The results revealed that the photosynthetic rate and stomatal conductance were found get reduced in the susceptible genotypes viz., Arka Surya, Arka Prabhath, Red Lady and Pusa Dwarf at all the stages of observation, while in tolerant genotypes such as Pusa Nanha, TNAU papaya CO8, they initially decreased at 7 dpi but found to be raised at $14 \mathrm{dpi}$ but again declined during the observation on $30 \mathrm{dpi}$. In IGH1 and $\mathrm{IGH} 2, \mathrm{P}_{\mathrm{N}}$ and gs were found to be increased at $7 \mathrm{dpi}$ but decreased afterwards. In susceptible genotypes, transpiration rate was found to be increased continuously upto 14 dpi and reduced at 30 dpi. The physiological parameters did not show any significant alterations in the photosynthetic rate, stomatal conductance and transpiration rate in the three Vasconcellea species evaluated

\section{Introduction}

Papaya (Carica papaya L., family Caricaceae) is considered as fourth most important fruit crop worldwide due to its acceptance amongst the consumers and food processing industries. Although, it has originated from tropical central America, the crop has spread throughout the tropics and sub tropics in other parts of the world due to its high nutritional value, consumer preference and ability to provide better revenue to the growers. Papaya fruit is a nutrition basket filled with vitamins, minerals, carbohydrates, proteins, iron, 
calcium and phosphorous. It is a rich source of vitamins having an approximate composition of $2020 \mathrm{IU}$ of vitamin A, $40 \mathrm{mg}$ of vitamin $\mathrm{B}_{1}$, and $46 \mathrm{mg}$ of vitamin $\mathrm{C}$ per $100 \mathrm{~g}$ of fruit (Dinesh, 2010).

The total area under cultivation of papaya has recorded a regular increase in the recent past but its production has not increased correspondingly owing to several biotic stresses such as various diseases caused by fungi, bacteria, phytoplasm and viruses. Among them, the global papaya production is seriously hampered by a devastating disease caused by virus known as Papaya Ring Spot Virus $(P R S V-P)$ which is transmitted by aphids in a non-persistent manner. This deadly disease causes losses as high as $70 \%$ of expected yield (Manshardt and Drew, 1998). No papaya varieties till date were identified for resistance to $P R S V-P$; whereas several species of Vasconcellea was reported to have heritable resistance to Papaya Ring Spot Virus such as $V$. cauliflora, $V$. cundinamarcensis and $V$. quercifolia (Drew et al., 1998). Evaluation of physiological parameters in relationship to $P R S V$ incidence may help to identify resistant accessions and also genetic functions regulating tolerance to disease Biomass production in plants greatly depends on the level of gas exchange between the plant and environment (Wenda-Piesik et al., 2016). The process of photosynthesis is greatly affected by biotic or abiotic stress. This is possibly through the alteration in organelle structures, pigment production and stomatal regulation. The response of the stress developed in the plants can be initially detected by net photosynthetic rate and related parameters.

After infection caused by pathogens, effect of $P R S V$ in the genotypes varies that in turn affects the plant growth characters via effect on physiological process. The present study was carried out to understand the differences in changes in photosynthetic related parameters in genotypes having varied responses to $P R S V$ by involving six Carica papaya varieties, two intergeneric hybrids of Carica papaya and Vasconcellea cauliflora and three Vasconcellea species

\section{Materials and Methods}

The experiment was conducted at ICARIndian Institute of Horticultural Research, Bengaluru during the period of June to August, 2017 under the insect proof glass house.

\section{Source of virus inoculum}

Susceptible cultivar ('Arka Prabhath') was inoculated with Papaya Ring Spot Virus-P and maintained inside insect proof net house and was used as the source of inoculum.

\section{Plant material}

Six cultivars of Carica papaya namely Arka Surya, Arka Prabhath (check), Red Lady, Pusa Dwarf, Pusa Nanha and CO8, two intergeneric hybrids of the cross Arka Surya and Vasconcellea cauliflora (IGH1 and IGH2) and three wild relatives $V$. cauliflora, $V$. goudotiana and $V$. cundinamarcensis were involved in this study. Three replications of twenty plants in each accession were maintained as per Randomized Block design.

\section{Method of inoculation}

Infected leaves from the susceptible cultivar maintained in the insect proof net house were homogenized in $0.1 M$ potassium phosphate buffer $(1: 5 \mathrm{w} / \mathrm{v})(\mathrm{pH} 7.0)$, two drops of $\square$ mercaptoethanol and pinch of sodium sulphite. The homogenate was squeezed through cotton wool and used as standard inoculum. The papaya plants at five leaf stage, the basal three leaves were mechanically inoculated on the 
upper surface of the leaves with the standard inoculum, using carborundum powder through 600 mesh as an abrasive. After 5 minutes of inoculation, the excess sap was washed off by distilled water. Control and inoculated plants were maintained separately in insect proof glass house and retained a temperature of 25$28^{\circ} \mathrm{C}$ and humidity of $75-80$ percent.

\section{Symptom expression}

Initial symptom of chlorotic spot on leaves at the site of inoculation at nursery stage was observed within 11-13 days post inoculation (dpi) in Carica papaya genotypes such as Arka Prabhath, Arka Surya, Pusa Dwarf and Red Lady, whereas in Pusa Nanha and TNAU Papaya $\mathrm{CO}$, the symptom expression was delayed and appeared at $23^{\text {rd }}$ day and $17 \mathrm{dpi}$ respectively. Intergeneric hybrids viz., IGH1 and IGH2 showed the initial symptom of chlorotic spots on $18^{\text {th }}$ day. No symptom expression was observed in the three wild relatives.

\section{Measurement of physiological parameters}

Leaves just above the inoculated ones (considered as 'systemic leaves') were observed both prior to inoculation as well as post inoculation after 7 days, 14 days and 30 days, for physiological parameters. The gas exchange parameters were measured between 9.30 AM to $11.00 \mathrm{AM}$ prior to inoculation as well as post inoculation after 7 days, 14 days and 30 days, using Portable Photosynthesis System, LI-6400 Xt (LiCor. Lincoln, Nebraska, USA). The instrument was properly calibrated to record net photosynthetic rate $\mathrm{P}_{\mathrm{N}}$ $\left(\square \mathrm{mol} \mathrm{m}^{-2} \mathrm{~s}^{-1}\right.$ ), stomatal conductance gs (mol $\left.\mathrm{m}^{-2} \mathrm{~s}^{-1}\right)$ and transpiration rate $\mathrm{E}\left(\mathrm{m} \mathrm{mol} \mathrm{m} \mathrm{s}^{-2}\right)$.

\section{Results and Discussion}

Based on symptom expression on the plants and growth, the genotypes evaluated were classified as susceptible (Arka Surya, Arka Prabhath, Red Lady and Pusa Dwarf), tolerant (Pusa Nanha, TNAU papaya CO8, IGH1 \&2) and resistant (Vasconcellea sp). The differential rates or changes in the physiological parameters viz., Net Photosynthetic Rate $\left(\mathrm{P}_{\mathrm{N}}\right)$, Stomatal conductance (gs) and transpiration rate (E) post inoculation as compared to pre inoculation stages in these genotypes are presented here. The observations are furnished in Table 1.

\section{Net photosynthetic rate $\left(\mathbf{P}_{\mathrm{N}}\right)$}

The net photosynthetic rate in plants before inoculation ranged from $3.17 \square \mathrm{mol} \mathrm{m}^{2} \mathrm{~s}^{1}$ in V: goudotiana to $9.72 \square \mathrm{mol} \mathrm{m} \mathrm{m}^{2}{ }^{1}$ in Arka Prabhath among the genotypes evaluated. Before inoculation, higher photosynthetic rate (9.72 $\square \mathrm{mol} \mathrm{m} \mathrm{m}^{-2}$ ) was observed in Arka Prabhath followed by Arka Surya (9.26 $\square \mathrm{mol}$ $\left.\mathrm{m}^{-2} \mathrm{~s}^{-1}\right)$ and Pusa Dwarf $\left(8.17 \square \mathrm{mol} \mathrm{m} \mathrm{m}^{-2}\right)$. The photosynthetic rates were observed to be lower in $V$. goudotiana $\left(3.17 \square \mathrm{mol} \mathrm{m}^{-2} \mathrm{~s}^{-1}\right)$ and intermediate in $V$. cauliflora (4.46 $\square \mathrm{mol}$ $\left.\mathrm{m}^{2} \mathrm{~s}^{1}\right)$, TNAU Papaya CO8 $\left(5.23 \square \mathrm{mol} \mathrm{m} \mathrm{m}^{-1}\right)$ and $V$. cundinamarcensis $\left(6.66 \square \mathrm{mol} \mathrm{m}^{-2} \mathrm{~s}^{-1}\right)$.

At $7 \mathrm{dpi}$, it ranged from $4.46 \square \mathrm{mol} \mathrm{m} \mathrm{m}^{2} \mathrm{~s}^{1}$ in $V$. cauliflora to $8.69 \square \mathrm{mol} \mathrm{m} \mathrm{m}^{2}$ in IGH2. At $14 \mathrm{dpi}, \mathrm{P}_{\mathrm{N}}$ reduced to a range of $4.16 \square \mathrm{mol}$ $\mathrm{m}^{2} \mathrm{~s}^{1}$ in V.cauliflora to $8.53 \square \mathrm{mol} \mathrm{m} \mathrm{m}^{2}$ in IGH2. The $\mathrm{P}_{\mathrm{N}}$ range was from $1.73 \square \mathrm{mol} \mathrm{m} \mathrm{m}^{2}{ }^{1}$

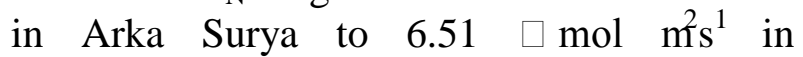
Vasconcellea cundinamarensis at $30 \mathrm{dpi}$ (Table 1).

At $7 \mathrm{dpi}$, significant decrease in $\mathrm{P}_{\mathrm{N}}$ was observed in the six Carica papaya cultivars evaluated while there was significant increase in $\mathrm{P}_{\mathrm{N}}$ in IGH1, IGH2, V.goudotiana and V.cundinamarcensis while there was no significant change in $\mathrm{P}_{\mathrm{N}}$ in V.cauliflora. At 14 dpi, except in V.goudotiana, V. cauliflora, Pusa Nanha and TNAU papaya CO8, in the 
other genotypes there was significant reduction in $\mathrm{P}_{\mathrm{N}}$ as compared to $\mathrm{P}_{\mathrm{N}}$ at $7 \mathrm{dpi}$. At 30 dpi, except in V.cauliflora, V.goudotiana and $V$. cundinamarensis, in all the other genotypes the $\mathrm{P}_{\mathrm{N}}$ was significantly reduced as compared to $\mathrm{P}_{\mathrm{N}}$ levels at $14 \mathrm{dpi}$. At $30 \mathrm{dpi}$, the photosynthetic rates were comparatively higher in TNAU Papaya CO8, IGH1, V.cauliflora and V.goudiatiana indicating that these genotypes have some adaptable mechanism to maintain reasonable rates of $\mathrm{P}_{\mathrm{N}}$ as compared to other genotypes.

Based on symptom expression on the plants and growth, the genotypes evaluated were classified as susceptible (Arka Surya, Arka Prabhath, Red Lady and Pusa Dwarf) tolerant (Pusa Nanha, TNAU papaya CO8, IGH 1 \&2)) and resistant (Vasconcellea $\mathrm{sp}$ )

In the susceptible genotypes, assimilate rate decreased continuously as the days progressed after $P R S V$ inoculation. Similar results were obtained after SCYLV infection in sugarcane, Sunflower chlorotic mosaic virus in sunflower, phytoplasma in grapevine (Lehrer and Komor, 2009; Arias et al., 2003; Bertamini et al., 2002). Generally RuBisco activity is the major limiting factor which eventually leads to chlorophyll breakdown (Izguirre-Mayoral et $a l ., 2002$ ) and it may be the cause of chlorotic symptoms in observed susceptible genotypes. The diversion of carbohydrates to virus replication in susceptible genotypes also may reduce the RuBisco synthesis and thereby the reduction in photosynthetic rate.

\section{Stomatal conductance (gs)}

The stomatal conductance ranged from 0.35 mol m $\mathrm{s}^{-2}$ (Arka Prabhath) to $0.77 \mathrm{~mol} \mathrm{~m}^{-2} \mathrm{~s}^{-1}$ (Arka Surya) in control plants of Carica papaya genotypes and intergeneric hybrids, while it ranged from $0.17 \mathrm{~mol} \mathrm{~m}^{-2} \mathrm{~s}^{-1}(V$. cauliflora) to $0.39 \mathrm{~mol} \mathrm{~m}^{-2} \mathrm{~s}^{-1} \quad(V$. cundinamarcensis) in the Vasconcellea species evaluated in the present study. Before inoculation, highest stomatal conductance of $0.77 \mathrm{~mol} \mathrm{~m}^{-2} \mathrm{~s}^{-1}$ was registered in Arka Surya and was on par by IGH2 $\left(0.67 \mathrm{~mol} \mathrm{~m}^{-2} \mathrm{~s}^{-1}\right)$ and lowest was recorded in $V$. cauliflora $(0.17 \mathrm{~mol}$ $\left.\mathrm{m}^{-2} \mathrm{~s}^{-1}\right)$ succeeded by $V$. goudotiana $(0.32 \mathrm{~mol}$ $\left.\mathrm{m}^{-2} \mathrm{~s}^{-1}\right)$ and $V$. cundinamarcensis $(0.39 \mathrm{~mol} \mathrm{~m}$ $\left.{ }^{2} \mathrm{~S}^{-1}\right)$.

Consequent to $P R S V$ inoculation at $7 \mathrm{dpi}$, gs ranged from $0.14 \mathrm{~mol} \mathrm{~m}^{-2} \mathrm{~s}^{-1}$ in $V$. cauliflora to $0.55 \mathrm{~mol} \mathrm{~m}^{-2} \mathrm{~s}^{-1}$ in Arka Surya. At $14 \mathrm{dpi}$, gs ranged between $0.13 \mathrm{~mol} \mathrm{~m}^{-2} \mathrm{~s}^{-1}$ in Arka

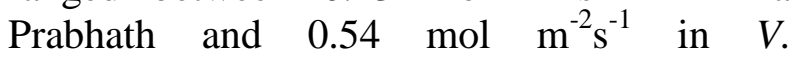
cundinamarcensis. The gs ranged from 0.05 mol m $\mathrm{m}^{-2}$ in Pusa Dwarf to $0.54 \mathrm{~mol} \mathrm{~m}^{-2} \mathrm{~s}^{-1}$ in $V$. cundinamarcensis at $30 \mathrm{dpi}$.

Stomatal conductance (gs) was decreased in Arka Surya, Arka Prabhath, Red Lady, Pusa Dwarf, TNAU Papaya CO8, IGH1 and IGH2 at 7 dpi. At $14 \mathrm{dpi}$, further decrease as compared to 7 dpi was observed in Arka Surya, Arka Prabhath and TNAU papaya CO8, while, other genotypes remain on par with gs levels at 7 dpi. At 30 dpi, except Pusa Nanha and IGH1, in all other genotypes the gs was significantly reduced as compared to gs levels at 14 dpi.

In resistant genotypes viz., $V$. cauliflora and $V$. goudotiana the stomatal conductance showed non-significant differences after inoculation, while in $V$. cundinamarcensis, increase in stomatal conductance was recorded after inoculation at 7dpi, $14 \mathrm{dpi}$ and $30 \mathrm{dpi}$. The genetic background of high stomata conductance in $V$. cundinamarcensis is worth further study.

In the susceptible genotypes, similar to photosynthetic rate, stomatal conductance decreased continuously as the days progressed after $P R S V$ inoculation. The reduction in photosynthetic rate might be due to the limited stomatal conductance. 
Table.1 Changes in parameters related to photosynthesis in response to $P R S V$ infection

\begin{tabular}{|c|c|c|c|c|c|c|c|c|c|c|c|c|c|c|c|}
\hline \multirow{2}{*}{$\begin{array}{l}\text { Varieties/ Wild } \\
\text { relatives }\end{array}$} & \multicolumn{5}{|c|}{ 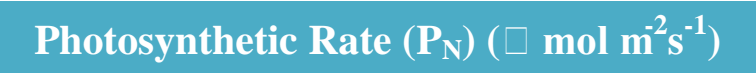 } & \multicolumn{5}{|c|}{ Stomatal conductance $(\mathrm{gs})\left(\mathrm{mol} \mathrm{m}^{-2} \mathrm{~s}^{-1}\right)$} & \multicolumn{5}{|c|}{ Transpiration rate $(E)\left(\mathrm{mmol} \mathrm{m}^{-2} \mathrm{~s}^{-1}\right)$} \\
\hline & $\mathrm{BI}$ & 7dpi & 14dpi & 30dpi & $\begin{array}{l}\text { Tukey's } \\
\text { HSD at } \\
1 \%\end{array}$ & BI & 7dpi & 14dpi & 30dpi & $\begin{array}{l}\text { Tukey's } \\
\text { HSD at } \\
1 \%\end{array}$ & BI & 7dpi & 14dpi & 30dpi & $\begin{array}{l}\text { Tukey's } \\
\text { HSD at } \\
1 \%\end{array}$ \\
\hline Arka Surya & ${ }^{\mathrm{a}} 9.26^{\mathrm{b}}$ & ${ }^{b} 8.38^{b}$ & ${ }^{\mathrm{c}} 6.57^{\mathrm{b}}$ & ${ }^{\mathrm{d}} 1.73^{\mathrm{k}}$ & 0.25 & ${ }^{\mathrm{a}} 0.77^{\mathrm{a}}$ & ${ }^{\mathrm{b}} 0.55^{\mathrm{a}}$ & ${ }^{\mathrm{c}} 0.48^{\mathrm{a}}$ & ${ }^{\mathrm{c}} 0.11^{\mathrm{b}}$ & 0.14 & ${ }^{c} 3.43^{d}$ & $\mathrm{~b}_{3.86^{\mathrm{cd}}}$ & ${ }^{\mathrm{a}} 4.44^{\mathrm{f}}$ & ${ }^{\mathrm{d}} 1.19^{\mathrm{g}}$ & 0.18 \\
\hline Arka Prabhath & ${ }^{\mathrm{a}} 9.72^{\mathrm{a}}$ & ${ }^{b} 7.36^{c}$ & ${ }^{\mathrm{c}} 5.44^{\mathrm{d}}$ & ${ }^{\mathrm{d}} 2.22^{\mathrm{j}}$ & 0.16 & ${ }^{\mathrm{a}} 0.35^{\mathrm{de}}$ & ${ }^{\mathrm{b}} 0.23^{\mathrm{de}}$ & ${ }^{\mathrm{c}} 0.13^{\mathrm{c}}$ & ${ }^{\mathrm{c}} 0.12^{\mathrm{b}}$ & 0.04 & ${ }^{b} 2.93^{f}$ & ${ }^{\mathrm{c}} 2.85^{\mathrm{f}}$ & ${ }^{\mathrm{a}} 3.97^{\mathrm{g}}$ & ${ }^{\mathrm{d}} 2.55^{\mathrm{e}}$ & 0.04 \\
\hline Red Lady & ${ }^{\mathrm{a}} 7.06^{\mathrm{de}}$ & ${ }^{\mathrm{b}} 6.27^{\mathrm{f}}$ & ${ }^{\mathrm{c}} 5.28^{\mathrm{de}}$ & ${ }^{d} 2.74^{g}$ & 0.22 & ${ }^{\mathrm{a}} 0.47^{\mathrm{bc}}$ & ${ }^{\mathrm{b}} 0.21^{\mathrm{de}}$ & ${ }^{\mathrm{bc}} 0.18^{\mathrm{c}}$ & ${ }^{\mathrm{c}} 0.10^{\mathrm{b}}$ & 0.09 & ${ }^{d} 2.19^{i}$ & ${ }^{\mathrm{c}} 3.21^{\mathrm{e}}$ & ${ }^{\mathrm{a}} 5.65^{\mathrm{b}}$ & $\mathrm{b}_{3.34^{\mathrm{c}}}$ & 0.11 \\
\hline Pusa Dwarf & ${ }^{\mathrm{a}} 8.17^{\mathrm{c}}$ & ${ }^{\mathrm{b}} 6.71^{\mathrm{e}}$ & ${ }^{\mathrm{c}} 6.10^{\mathrm{c}}$ & ${ }^{d} 2.12^{j}$ & 0.31 & ${ }^{\mathrm{a}} 0.45^{\mathrm{cd}}$ & ${ }^{\mathrm{b}} 0.32^{\mathrm{cd}}$ & ${ }^{\mathrm{b}} 0.33^{\mathrm{b}}$ & ${ }^{\mathrm{c}} 0.05^{\mathrm{b}}$ & 0.08 & ${ }^{b} 3.90^{c}$ & ${ }^{b} 4.17^{c}$ & ${ }^{\mathrm{a}} 4.83^{\mathrm{e}}$ & ${ }^{\mathrm{c}} 1.00^{\mathrm{h}}$ & 0.29 \\
\hline Pusa Nanha & ${ }^{\mathrm{a}} 6.70^{\mathrm{ef}}$ & ${ }^{\mathrm{b}} 6.14^{\mathrm{g}}$ & ${ }^{\mathrm{a}} 6.71^{\mathrm{h}}$ & ${ }^{c} 3.22^{f}$ & 0.41 & ${ }^{\mathrm{a}} 0.49^{\mathrm{bc}}$ & ${ }^{\mathrm{a}} 0.51^{\mathrm{ab}}$ & ${ }^{b} 0.14^{c}$ & ${ }^{\mathrm{b}} 0.13^{\mathrm{b}}$ & 0.05 & ${ }^{\mathrm{c}} 1.16^{\mathrm{j}}$ & ${ }^{\mathrm{a}} 4.14^{\mathrm{c}}$ & ${ }^{b} 1.65^{j}$ & ${ }^{b} 1.75^{f}$ & 0.14 \\
\hline TNAU papaya CO8 & ${ }^{\mathrm{a}} 5.23^{\mathrm{g}}$ & ${ }^{\mathrm{b}} 4.97^{\mathrm{h}}$ & ${ }^{\mathrm{a}} 5.16^{\mathrm{e}}$ & ${ }^{\mathrm{c}} 4.72^{\mathrm{b}}$ & 0.19 & ${ }^{\mathrm{a}} 0.43^{\mathrm{cd}}$ & ${ }^{\mathrm{b}} 0.28^{\mathrm{cd}}$ & ${ }^{\mathrm{c}} 0.15^{\mathrm{c}}$ & ${ }^{\mathrm{c}} 0.15^{\mathrm{b}}$ & 0.12 & ${ }^{\mathrm{b}} 6.67^{\mathrm{a}}$ & ${ }^{\mathrm{c}} 3.62^{\mathrm{d}}$ & ${ }^{\mathrm{a}} 6.94^{\mathrm{a}}$ & $\mathrm{d}_{3.44^{\mathrm{c}}}$ & 0.11 \\
\hline IGH1 & ${ }^{b} 6.43^{f}$ & ${ }^{\mathrm{a}} 8.59^{\mathrm{a}}$ & ${ }^{\mathrm{c}} 5.37^{\mathrm{d}}$ & ${ }^{d} 4.54^{c}$ & 0.24 & ${ }^{\mathrm{a}} 0.56^{\mathrm{b}}$ & ${ }^{\mathrm{b}} 0.24^{\mathrm{de}}$ & ${ }^{\mathrm{b}} 0.31^{\mathrm{b}}$ & ${ }^{\mathrm{b}} 0.25^{\mathrm{a}}$ & 0.14 & ${ }^{c} 4.13^{b}$ & $\mathrm{~b}_{4} 4.57^{\mathrm{b}}$ & ${ }^{\mathrm{a}} 5.30^{\mathrm{c}}$ & ${ }^{b} 4.57^{a}$ & 0.18 \\
\hline IGH2 & ${ }^{b} 7.33^{d}$ & ${ }^{\mathrm{a}} 8.69^{\mathrm{a}}$ & ${ }^{\mathrm{a}} 8.53^{\mathrm{a}}$ & ${ }^{\mathrm{c}} 2.49^{\mathrm{h}}$ & 0.22 & ${ }^{\mathrm{a}} 0.67^{\mathrm{a}}$ & ${ }^{\mathrm{b}} 0.41^{\mathrm{bc}}$ & ${ }^{\mathrm{b}} 0.32^{\mathrm{b}}$ & ${ }^{\mathrm{c}} 0.15^{\mathrm{b}}$ & 0.17 & ${ }^{\mathrm{c}} 4.18^{\mathrm{b}}$ & ${ }^{b} 4.85^{b}$ & ${ }^{\mathrm{a}} 4.95^{\mathrm{d}}$ & ${ }^{\mathrm{d}} 2.96^{\mathrm{d}}$ & 0.10 \\
\hline V. cauliflora & $4.46^{\mathrm{h}}$ & $4.46^{j}$ & $4.16^{\mathrm{g}}$ & $4.35^{\mathrm{d}}$ & NS & $0.17^{\mathrm{f}}$ & $0.14^{\mathrm{e}}$ & $0.15^{\mathrm{c}}$ & $0.14^{\mathrm{b}}$ & NS & $2.62^{\mathrm{g}}$ & $2.95^{\mathrm{ef}}$ & $2.48^{\mathrm{i}}$ & $2.91^{\mathrm{d}}$ & NS \\
\hline V. goudotiana & $4.17^{\mathrm{i}}$ & $4.79^{\mathrm{i}}$ & $4.92^{f}$ & $4.16^{\mathrm{e}}$ & NS & $0.32^{\mathrm{e}}$ & $0.34^{\mathrm{cd}}$ & $0.32^{b}$ & $0.34^{\mathrm{a}}$ & NS & ${ }^{\mathrm{c}} 2.38^{\mathrm{h}}$ & ${ }^{\mathrm{a}} 5.44^{\mathrm{a}}$ & $\mathrm{b}_{3.64^{\mathrm{h}}}$ & ${ }^{\mathrm{c}} 2.42^{\mathrm{e}}$ & 0.58 \\
\hline V. cundinamarcensis & $6.66^{\mathrm{f}}$ & $7.09^{d}$ & $6.56^{\mathrm{b}}$ & $6.51^{\mathrm{a}}$ & NS & $0.49^{\mathrm{bc}}$ & $0.54^{\mathrm{ab}}$ & $0.54^{\mathrm{a}}$ & ${ }^{\mathrm{a}} 0.55^{\mathrm{a}}$ & 0.12 & $3.15^{\mathrm{e}}$ & $3.75^{\mathrm{d}}$ & $3.92^{\mathrm{g}}$ & $3.64^{\mathrm{b}}$ & NS \\
\hline Mean & 6.74 & 6.68 & 5.62 & 3.53 & & 0.46 & 0.34 & 0.28 & 0.17 & & 3.34 & 3.95 & 4.34 & 2.71 & \\
\hline $\mathrm{CV}(\%)$ & 1.51 & 0.49 & 0.83 & 0.56 & & 6.30 & 11.27 & 7.28 & 16.26 & & 0.73 & 2.50 & 0.64 & 1.56 & \\
\hline SE (d) & 0.08 & 0.03 & 0.04 & 0.02 & & 0.02 & 0.03 & 0.02 & 0.02 & & 0.02 & 0.08 & 0.02 & 0.03 & \\
\hline Tukey's HSD at 1\% & 0.36 & 0.12 & 0.17 & 0.07 & & 0.104 & 0.14 & 0.072 & 0.100 & & 0.088 & 0.353 & 0.099 & 0.151 & \\
\hline
\end{tabular}


This has been previously reported in tobacco cultivars infected by poty viruses $P V Y$ and Potato virus A (Ryslava et al., 2003). Reduction in stomatal conductance also indicated a high accumulation of viral aggregates inside the guard cells (Schnkova et al., 2005). This might negatively affect the stomatal conductance in susceptible genotypes. In contrast, the virus replication in resistant genotypes was possibly restricted by different defense mechanisms and hence may cause limited accumulation of viral aggregates and thus non-significant reduction in stomatal conductance.

\section{Transpiration rate $(\mathrm{E})$}

Among the genotypes, highest transpiration rate of $6.67 \mathrm{mmol} \mathrm{m}^{-2} \mathrm{~s}^{-1}$ prior to inoculation was observed in TNAU Papaya CO8, followed by IGH2 (4.18 mmol m $\left.\mathrm{m}^{-2} \mathrm{~s}^{-1}\right)$ and IGH1 (4.13 mmol m $\mathrm{m}^{-2}$ ) (Table 1) and lower values were recorded in Pusa Nanha (1.16 mmol m $\mathrm{m}^{-2}$ ) and Red Lady (2.19 mmol $\left.\mathrm{m}^{-2} \mathrm{~s}^{-1}\right)$. At $7 \mathrm{dpi}$, the transpiration rate ranged from $2.85 \mathrm{mmol} \mathrm{m}^{-2} \mathrm{~s}^{-1}$ in Arka Prabhath to $5.44 \mathrm{mmol} \mathrm{m} \mathrm{m}^{-2} \mathrm{~s}^{-1}$ in $V$. goudotiana. The transpiration rate at $14 \mathrm{dpi}$ was ranged from $1.65 \mathrm{mmol} \mathrm{m}^{-2} \mathrm{~s}^{-1}$ in Pusa Nanha to $6.94 \mathrm{mmol}$ $\mathrm{m}^{-2} \mathrm{~s}^{-1}$ in TNAU papaya CO8. At $30 \mathrm{dpi}$, the levels of $\mathrm{E}$ ranged from $1.00 \mathrm{mmol} \mathrm{m} \mathrm{m}^{-2}$ in Pusa Dwarf to $4.57 \mathrm{mmol} \mathrm{m}^{-2} \mathrm{~s}^{-1}$ in IGH1.

In Arka Surya, Arka Prabhath, Red Lady, Pusa Dwarf, TNAU papaya CO8, IGH1 and IGH2 transpiration rate increased significantly at 14 dpi but declined significantly at 30 dpi. In Pusa Nanha, significant increase in transpiration rate was observed at $7 \mathrm{dpi}$ and further declined at 14 dpi and 30 dpi as compared to 7 dpi. Transpiration rates remained unchanged in $V$. cauliflora and $V$. cundinamarcensis, while in $V$. goudotiana the increase in transpiration rate was recorded at $7 \mathrm{dpi}$ and declined further at 14 and $30 \mathrm{dpi}$ as compared to $7 \mathrm{dpi}$.
In susceptible genotypes, the transpiration rate was found increased significantly upto 14 days post inoculation and further declined probably with lower metabolic rates. This results was contradictory to Bertamini et al., (2005), who reported significant reduction in transpiration after grapevine leaf rollassociated virus in grapevine. Disrupted water supply was associated in water stress leading to symptoms viz., chlorosis, wilting. Generally reduced stomatal conductance was associated with transpiration rate. In this study increase in transpiration rate in susceptible genotypes after $P R S V$ inoculation was observed and this might be because of the stress developed inside the plant system as the plant tissues may be in demand for more assimilates to regain its homeostasis. The physiological parameters in Vasconcellea species were comparatively less affected or not significantly impacted by $P R S V$ infection indicating that the resistance mechanisms prevailing in these genotypes have the capacity to maintain physiological functioning of the plant inspite of viral incidence. The physiological parameters were found to be influenced greatly within a short span of infection ( $7 \mathrm{dpi}$ ) and the tolerant or resistant genotypes were able to maintain the important physiological parameters related to photosynthesis at a reasonable level subsequently (14 or $30 \mathrm{dpi}$ ) and recover as compared to severely susceptible genotypes. The genetic basis of such regulation and adaptation in the Vasconcellea species and as well as in the tolerant Carica papaya genotypes viz., Pusa Nanha, TNAU Papaya CO.8 and IGH-1 which helps to achieve homeostasis for effective functioning of photosynthetic system further needs to be studied.

\section{References}

Arias, M.C., S. Lenardon and E. Taleisnik. 2003. Carbon metabolism in sunflower 
plants infected with the Sunflower chlorotic mottle virus. J. Phytopathol., 151: 267-273.

Bertamini M., N. Nedunchezhian., F. Tomasi and M.S. Grando. 2002. Phytoplasma [Stolbur-subgroup Bois Noir-BN)] infection inhibits photosynthetic pigments, ribulose-1,5- bisphosphate carboxylase and photosynthetic activities in field grown grapevine (Vitis vinifera L. cv. Chardonnay) leaves., Physiol. Mol. Plant Pathol., 61: 357366.

Bertamini M., U. Malossini, K. Muthuchelian and N. Nedunchezhian. 2005. Physiological response of field grown grapevine (Vitis vinifera L. cv. Marzemino) to grapevine leafrollassociated virus (GLRaV-1). Phytopathol. Mediterr., 44 : 256-265.

Dinesh, M. R. 2010. Papaya Breeding In India. Acta Hortic., 851: 69-76.

Drew, R.A., C.M. O'Brien and P.M. Magdalita. 1998. Development of interspecific Carica hybrids. Acta Hortic., 461: 285-291.

Izaguirre-Mayoral M.L., O. Carballo., C. Alceste., M. Romano and H.A. Nass.2002. Physiological performance of asymptomatic and yellow leaf syndrome-affected sugarcanes in Venezuela. J Phytopathol., 150:13-19.

Lehrer, T.A. and Komor, E. 2009. Carbondioxide assimilation by virus free sugarcane plants and by plants which were infected by Sugarcane Yellow Leaf Virus. Physiological and Molecular Plant Pathology., 73: 147153.

Manshardt, R.M. and R.A. Drew. 1998. Biotechnology of papaya. In: Intl. Symposium on Biotechnol. Tropical and Subtropical Species 2,461:65-74.

Ryslava.H., K. Muller., S. Semoradova., H. Synkova and N. Cerovska. 2003. Photosynthesisand activity of phosphoenolpyruvate carboxylase in Nicotiana tabacum L. leaves infected by Potato virus $\mathrm{A}$ and Potato virus $\mathrm{Y}$, Photosynthetica, 41: 357-363.

Synkova, H., Sarka Semoradova., Schnablova, R., Muller, K., Pospisilova, J., Ryslava. H., Malbeck, J. and Cerovska, N. 2006. Effects of biotic stress caused by Potato virus Y onphotosynthesisin ipt transgenic and control Nicotiana tabacum L. Plant Science, 171:607-616.

Wenda-Piesik, A., W. Krzesinski., A. Nowak., M. Kazek and M. Tomaszewska-Sowa. 2017. Response of gas exchange to leaf piercing explained by piecewise linear regression for two developmental forms of rape plant (Brassica napus L. Ssp. Oleifera Metzg). Acta Biologica Cracoviensia., 59: 81-92.

\section{How to cite this article:}

Linta Vincent, K. Soorianathasundaram, M.R. Dinesh and Shivashankara, K.S. 2018. Impact on Physiological Parameters upon PRSV Infection in Different Genotypes of Carica papaya L. and Vasconcellea species. Int.J.Curr.Microbiol.App.Sci. 7(09): 2736-2742. doi: https://doi.org/10.20546/ijcmas.2018.709.340 